\title{
ESPINHEIRA FILHO, Ruy. Estação infinita e outras estações. Rio de Janeiro: Bertrand Brasil, 2012.
}

Hildeberto Barbosa Filho ${ }^{1}$

Universidade Federal da Paraíba
1 Professor titular

da Universidade

Federal da Paraíba

Estação infinita e outras estações (Bertrand Brasil, 2012) é o título da mais recente reunião da poesia de Ruy Espinheira Filho. Houve outras, portanto. Morte secreta e poesia anterior (Philobiblion/Pró-Memória - INL, 1984); Poesia reunida e inéditos (Record, 1998); Antologia poética (COPENE, 1996) e Melhores poemas de Ruy Espinheira Filho (Global, 2011), organização de Sérgio Fazeira Martagão Gesteira, precedem, assim, a atual publicação que, se não fecha um ciclo, um vasto ciclo de criação, põe à disposição do leitor a plenitude de uma dicção lírica das mais férteis e mais memoráveis da poesia brasileira contemporânea.

"Estação infinita" me parece um conceito possível de poesia. Na sua condensação semântica, parece habitar um conjunto variado de motivações e temáticas, sempre repassadas pelo fio condutor do tempo e da memória, sobretudo quando se pensa na conexão ambígua e antitética que os mobiliza na história particular e única de cada poema. Se o tempo, normalmente aceite na perspectiva heraclitiana, tende a fluir como as águas de um rio, a memória como que paralisa o fluxo irredutível das experiências vividas. Dito de outra forma: na poesia do poeta baiano, o tempo para, e as águas desse rio em movimento se estratificam na "cacimba" da memória, como bem observa Miguel Sanches Neto, em sugestivo posfácio a Elegia de agosto e outros poemas (2005).

Creio ser essa dialética lírica um dos nervos centrais na poesia de Ruy Espinheira Filho. O vivido, o plenamente vivido, aqui, se se completou no processo natural que ocorre sob a égide racional da cronologia, estranhamente não passou; poeticamente não se perdeu, pois a memória categoria poética por excelência - possui o poder de reter e de preservar, no presente, o calor, a magia, o gosto e "a dor das coisas que passaram”, do emblemático verso camoniano.

Em certo sentido, tais experiências, que vão se transfigurar esteticamente no corpo das palavras, permanecem, não importa se dolorosas ou felizes, na alquimia de uma plenitude que não se dissipa e que viola as regras fatais do tempo. É como diz John Keats, no primeiro verso de "Endimião", na tradução de Péricles Eugênio da Silva Ramos: "Tudo que é belo é uma alegria para sempre”, ou, em outra cadência poética, como sugere Carlos 
Drummond de Andrade, no terceto final de "Memória": "Mas as coisas findas, / muito mais que lindas, / essas ficarão".

Pois bem: memória e tempo, sobretudo o valor do olhar retrospectivo e a diretriz avaliadora calcada no afeto, na empatia e na capacidade de filtrar o ingrediente essencial das coisas, dos seres e dos acontecimentos, funcionam como fusos que imprimem unidade e identidade ao tecido poético do autor de As sombras luminosas (1981).

A infância, os mortos, o pai, a cidade, as perdas, os amores, a poesia, o exílio, exílio na vida e na linguagem, são recuperados a partir do sonho que preside o enigma da criação poética. Diria que, se o homem, isto é, o ser empírico, não supera a agonia da constatação de que tudo está irremediavelmente perdido, perdido porque se esgotou nos limites do tempo, ou porque "poderia ter sido e não foi", como assinala Manuel Bandeira, em verso inesquecível, o poeta, com seus poemas de leve e intenso lirismo, transmuta essa agonia na vitória dos vocábulos, no lago translúcido e transtemporal das imagens poéticas, garantindo, assim, no corpo do poema, algum sentido àquela inevitável agonia. Por conseguinte, o sentido das vivências, no plano histórico e material do cotidiano, só se descortina, em sua substância radical, no plano imaterial e mágico da percepção poética.

Em "Descoberta” (p.41), poema de seu primeiro livro, Heléboro (1974), o poeta reflete sobre isto. Vejamos alguns versos: "Só depois percebemos / o mais azul do azul, / olhando, ao fim da tarde, / as cinzas do céu extinto. // Só depois é que amamos / a quem tanto amávamos; / e o braço se estende, e a mão / aperta dedos de ar. (...) Só depois é que sabemos / lidar com o que lidávamos. / E meditamos sobre esta / inútil descoberta // enquanto, lentamente, / da cumeeira carcomida / desce uma poeira fina / e nos sufoca”.

Tal ironia sem consolo, que se inscreve "sobre a jurisdição movediça das coisas irremediavelmente perdidas”, segundo Iacyr Anderson Freitas, em sólido estudo acerca da poesia de Ruy Espinheira Filho, persiste em todo poemário dessa "Estação infinita”, integrando também o último texto da reunião, intitulado "70 anos”. Leiamos as duas últimas estrofes: “Não pude deixar de errar / inúmeras vezes, /nem evitar a derrota de tantos sonhos, / nem as perdas / com seus vastos sofrimentos / para sempre renovados / na memória. // Agora, porém, / quando manifesto meu desejo maior / e mais sábio, / chegou a hora de cessar / o efêmero. E então afirmo aqui / a minha vontade / de ser esta cálida estação / a Eternidade, / prevalecendo sobre o que foi / até agora / o pesadelo de um deus doente / que criou a vida para vê-la sofrer e se perder / sem sentido algum”.

Ora, se não há sentido algum nesse projeto de um "deus doente”; se tudo passa, se tudo perece, se tudo vira pó, se tudo apodrece e se não há paraíso, há, no entanto, uma "cálida estação", uma "estação infinita”, a 
“Eternidade”, isto é, a poesia como forma de redenção. Poesia como linguagem da memória; memória como linguagem do sonho. 